\title{
Sources of Occupational Stress among Secondary School Administrators in Kano State, Nigeria
}

\author{
Adebola O. Jaiyeoba \& Mukhtari Ado Jibril
}

\begin{abstract}
The study identified the sources of occupational stress in secondary school managers in Kano state, Nigeria. Survey design was used and a random sampling was used to select the study sample, which consisted of 421 school managers. An inventory, the School Managers Sources of Stress Inventory was used to collect data. The data was analysed using simple percentage to answer the two research questions raised. The findings showed that, Administrative routine, Work load, and Conflicting demands and roles between work and family were the highest sources of stress. Also, $77.5 \%$ of the respondents reported that their job was stressful.
\end{abstract}

\section{Introduction}

In the Nigerian school system, the functions of managing and administering the school falls on the Principal, who is assisted by the Vice Principal and others such as the Senior Master and Mistresses. The school principal and his vice are regarded as custodians of an enterprise comprising considerable investment of resources in terms of finances, facilities and human skills. They are expected to preside over and manage the entire school. Being important persons in the school system, they have the overall task of managing the schools by ensuring good, balanced academic programmes, student teacher progress and proper supervision of work as well as effective leadership. The ability of the school managers to withhold, contain and contend with the various school responsibilities, challenges and functions will largely depend on their capacity and capability.

School managers to be able to function in this wise, will have to be able to perform several functions that demands them to be not only 
experienced, but competent in these duties. The expectations on them necessitated that they supervise the delivery lines and activities of their individual schools. As much as possible, they are to create a very conducive atmosphere that would allow for maximum attainment of school goals and objectives and the educational as a whole.

The environment within which they operate cannot be free of problems that are typical of a populous African nation with a high demand for education. Some of these problems include over population of students; problems with the school plant; ill- equipped and inadequate teachers to cope with the workload; students with poor academic backgrounds; poor funding that effects management; students negative attitude towards learning; parental ambivalence towards the educational well - being of their children; low motivation; low performance and overall lackadaisical attitudes of teachers towards work; personal problems including role conflict; societal problems and pressures; financial problems; domestic worries; and a lot more.

The school managers in Kano, Nigeria are not immune to all these problems. Against all these odds, the school managers are expected to be competent professionals in their duties. Teachers and students as well as parents and other stakeholders, look up to them to meet up with their various needs. They are to manage the meagre resources at their disposal to attain results. They are also to promote useful and profitable interaction of minds within the school community through various media; thus bringing about the needed mutual confidence in pooling experiences for effective problem solving. They are similarly to establish an atmosphere that will ensure effective management of the curriculum and its application to students' needs, aims, objectives and aspirations of the immediate environment and the nation. As leaders, they are seen as those whose examples transcend their precepts at work, play, in the office/school. They show examples by patience, amicability, kindness, considerations and genuineness of interest of their students and teachers. Hoyle (1989) pointed out that, the role of the school manager is charged and overloaded with 
expectations to the point at which if the school head were to meet them all will, risk burnout. Also, Ajayi (1995) alluded to this fact about the expectations of the school manager as an executive, if he is to perform in the field of management:

This makes the school manager vulnerable to stress which may be mild or major, depending on environmental factors as well as the personality of the individual executive. As those who have to make things work in the organisation, they cannot but be exposed to a lot of stressful events.

Like all formal organisations, the school system has specific administrative tasks and functions to be performed by the manager. In the field of management, several scholars from the scientific management theorists like Fredric Taylor and Henri Fayol, through the Human Relationists like Elton Mayo, Mary Parker Follet, to the Behaviourists like Lyndall Urwick, Gullick and Chester Barnard, have attempted to define what these functions should be. These are in addition to the professional functions that the school manager is to perform in the same way.

The complexities of life, both private and organisational have made stress to be an inevitable thing in our lives. The individual at work is always faced with some form of difficulty or painful experience and which results in stress that could either are a damaging factor to the individual's productivity, and in very rare case it may obtain, a challenging motivator. For instance, a job may require too much or too little from a person. Almost any aspect of the job environment is capable of producing stress.

Occupational stress remains one of the major causes of premature death world-over. As a result, clinical and health psychologists are increasingly becoming involved with clients identified as high risk group individuals either formally as part of preventive programme 
(Bennett \& Carrol,1998) or informally through contact with general practitioners(Iwuji,1999).

According a review by the Department of Health and Human Services (DHHS, 1988), there are approximately 110 million workers in the United Istates who are exposed to a wide variety of occupational hazards that can pose significant risks to their health and most of which are stress related(Levi,1990). Similarly, Doctor \& Doctor (1994) stated that, life style stressors contribute greatly, more than environmental, biological and other factors to premature death. A Word Health Organisation(WHO) report stated that, about one half of the entire working population are unhappy in their jobs and as many as $90 \%$ may be spending much of their energy and time in work that brings them no closer to their goals in life. About $75 \%$ of those who consult psychiatrists are experiencing problems that can be traced to lack of job satisfaction, or inability to unwind (Levi, 1987).

The Swedish Government Commission for Work Environment and Health Report (1990) submitted that, there are adverse conditions of work among professionals. A common and possibly decisive denominator of these work conditions is that which expose workers to a combination of high psychosocial stress and physical work load and a low level of decision latitude (Karasek \& Theorell, 1990 and Levi, 1990).

The teaching profession, of which school principals and viceprincipals as managers belong, can rightly be said to be seen as one stressful job. This is evident in the overwhelming frustrating situations within which they function in Kano state. As such therefore, many sources of stress can as well be identified in their job. As pointed out in the foregone submissions, principals and vice principals as school managers, are prone to complain about a variety of somatic concerns. In an era of globalisation and reform agendas in education, the leadership to be provided by them is extremely important. But they can unfortunately be overwhelmed by conflicting expectations that 
had become associated with their role within the educational community.

\section{Problem of the study}

Considering the fact that the school manager has a lot of responsibilities and expectations loaded on him, this therefore leaves no doubt that the school manager can easily get stressed as a result of the performance of the functions expected of him in that capacity. It has been observed that, school managers in Kano State go through a number of daily routines as schedules of activities. Several of these activities can be said to be quite tasking if not out rightly demanding and extremely stressful. This in effect can bring about the much referred to occupational stress. This study is therefore concerned with identifying the sources of stress among school managers in Kano State, Nigeria.

\section{Research Questions}

1. What are the sources of stress among school managers stressed in Kano State, Nigeria?

2. To what extent are the school managers in Kano State, Nigeria stressed?

\section{Methodology}

The design adopted for the study was a descriptive survey of the sources of stress among school managers in Kano State, Nigeria. The subjects for the study consisted of a total of 183 schools (150 public and 55 private). The total number of respondents was therefore 429 school managers, which are principals and vice-principals. To that end, Stratified random sampling technique was used to select the sample.

The data for the study was collected through the use of Researcher designed questionnaire tagged The School Managers Source of Stress Inventory (SMSSI). The inventory required the respondents to rank 18 items in the order to which they caused stress at work, and an item 
that required the respondents to make an overall assessment of the extent to which they considered their job as stressful. The vetted for face validity after which adjustment where made before the reliability of the inventory was determined using the test-retest method and a correlation coefficient(r) obtained was 0.83 .

\section{Data Analysis and Results}

The data collected for this study was analysed simple percentage to facilitate answering the two research questions raised in the study. Out of the total number of 429 questionnaires that where distributed, a total of 342 where returned and used for the data analysis. The analysis and findings of the study are presented in the following tables.

Table 1 gave the school managers' sources of stress. In the Table, the sources of stress (i.e., Occupational, Domestic and Economic stressors) are arranged in hierarchical (rank) order with respect to frequency and percentage eight. Accordingly therefore, occupational stressor (Administrative Routine) was the highest source of stress, followed by Work load and Conflicting Demands and Roles between Work and Family; Poor and Unserious Students; Students Indiscipline and Gangstarism; Next was Poor Work Environment and Lack of Resources; Economic and Financial Problems; social Problems and Lack of Autonomy in Execution of Responsibilities; Family Pressures; Official Pressure and Expectations; Group Pressure and Poor Social Image; then Pressure from Parents and Problems in Curriculum Implementation; and lastly, Pressure from Parents Teachers Association.

Table 2 showed responses on the general question; To what extent do you consider your job stressful? From the table, it can be observed that the number of responses for Not stressful is 77(22\%), Stressful is $111(32.5 \%)$, Very stressful is $101(29.5 \%)$ and Extremely stressful is $53(15.5 \%)$. On the whole, it could be seen that $265(77.48 \%)$ of the respondents found their job between stressful to extremely stressful. It 
could then be deduced that $77.48 \%$ of the school managers found their job stressful and so are stressed.

\section{Discussions}

Two basic questions were raised in this study. The discussion will therefore be based on these questions. The first basic question was concerned with the sources of stress among school managers? The inventory used in this study basically was meant to answer this.

Table 1 showed the most significant sources of stress in a ranked order. These accordingly, could be assumed as the sources of stress as identified by the mangers themselves. This is so as they constitute the basic, most essential and if not religious routine of the school managers. Every one of them, as a must, has to operate on a set of administrative routine, operate on a work load, which has extensive boundaries and markers. In fact these two occupational stressors constitute perhaps the whole gamut of the stresses of the school managers. Ordinarily, they are expected to put in a lot of their energies to the work and at the same time put in long hours. In the literature, French \& Caplan (1973) identified workload as a source of occupational stress and also specifying quantitative and qualitative overload. Mostly with the school managers is the quantitative overload, i.e. too much work to do and the tendency to work long hours.

This could perhaps be as a result of poor delegation or no delegation at all or maybe it is a function of a host of other functions associated with administrative routine and workload. That even with adequate delegation, it is not possible for the school heads to escape from quantitative overload. For instance, there are some problems which they as the school have to solve by themselves or attend to personally, give advice, offer directives, supervise, and attend top functionary meetings many of which are unscheduled, perform a host of other roles which are incumbent on them, etc. It can be argued that, Work role conflict (a domestic stressor), as a source of stress for the school managers can be linked to lack of autonomy for both public and 
private school managers. Lack of adequate information about work can create ambiguities, conflicts and distortions which will affect the person at the receiving end. Many an instance the manager gets caught in the web of such conflicts and so will be rooted and stagnant until when they are able to obtain clearance and clarifications before they act.

It is understood that school managers have concern for their students being serious, disciplined and of good dispositions. They suffer the shame and brunt of the failings and misbehaviour of their students. In a situation where a school consistently records poor results, or is known for unserious and unruly students, parents find it convenient to withdraw their children, and teachers seek for transfers. The same goes for the tone of discipline. School heads that certainly have to with these problems of poor and undisciplined students (as occupational stressor), will have to go through a lot. Studies have shown that students lack of discipline and motivation, as well as students misbehaviour were principal sources of stress and burnout among teachers and school heads (Gonzalez, 1994 and Quarles, 1996).

In the same light, school managers cannot attain any goal or objective of educational system without a convenient work environment and resources. A common feature of our schools is the absence of resource materials for effective teaching and learning to take place. Even if they existed, they are highly insufficient. This is ironically and surprisingly common to both public and private schools. It is only very few school managers who could boost of conducive environment and resources. With the absence of succour, the school heads have to make do and contend with what is available to them. This therefore a lot of problems for them while trying to produce for their teachers and students what is very meagre or nonexistent. Borg et al. (1991) had established that a key factor associated with stress among school teachers is lack of resources. 
Another stressor which fell in the group of economic stressors to the school to the school heads was found to be economic and financial problems. Abouserie (1991) identified that financial difficulties is one of most significant causes of stressing the life of academics. In this study, the relevance of economic and financial problems as a source of stress is equally high. Even though it is eighth in ranking, it is the first stressor outside work. The significance of this as a stressor cannot be over estimated. Most school managers have responsibilities and obligations irrespective of age, sex, and the type of school. Even if it could be assumed that with the recent increases in teacher's salaries, the teachers have started reaping their rewards on earth (not forgetting delayed salaries and that many private school managers are yet to enjoy the new salaries). Many school heads lack subventions. The levies and fees collected are not enough to manage the schools. A number of school heads spend out of their pockets to run the schools in spite of reimbursements being delayed or not paid at all (they cannot permit their schools to grind to a halt).

It has also been shown that social problems (domestic stressor) and lack of autonomy (occupational stressor) were the next stressors for the school managers. It is understandable that as human beings, they are not immune to the prevailing problems within the society. Among many of such is inflation, crimes, job security, deflating economy, poor social services, HIV/AIDS etc. although social problems within the society might have no direct linkage as a stressor on the job, lack of autonomy certainly would. This poses as a stressor possibly due to the fact that in most instances school managers are tied down to only taking directives. From admission of students, redeploying teachers, discipline of teachers and non academic staff, selection and purchase of materials, repairs, conduct of public examinations, spending have to be cleared from above, etc. in most cases they act as on instructions and directives, and the directives either do not come regularly or clearly and not on time or are conflicting. This erodes their autonomy as professionals, as they would have to be running around the zonal offices or the headquarters to seek for clarifications. As for the private 
schools, they had to seek for it from Boards or Ministry of education headquarters. With such ambiguities in their situations, one finds that their autonomy is being eroded therefore creating an unhealthy and unpalatable situation. Khan et al. (1984) pointed out that those who suffer from role ambiguity, experience lower job satisfaction, higher job related tension, greater futility, and a lower self-confidence. This position has also been buttressed by French and Caplan(1970), who established that role ambiguity is significantly related to lower job satisfaction. Other sources of stress identified in the study as affecting managers at work and which are outside the work setting include the family, a domestic stressor. The family setting can provide the individual with all the support and buffer to stress and hectic routine of work. But in a situation where the family does not, and rather poses additional problems, constant crisis and challenges to the individual, then there will be problems. In effect, conflicts in marriage, home and family can adversely affect the individual. This has been proved by Gowler and Legge (1975); Copper and Marshall,(1978) and Kakabadse (1982).

Also when one juxtaposes the varying pressures, either as occupational or domestic stressors, school managers go through; such as bureaucratic re-tapism and officialdom, pressure from parents, teachers, certainly one will appreciate that each of these has demands and expectations to which they have to conform to or meet up with. Some of these pressures could be certain and realistic, while others can be simply unbelievable. If it is considered for instance, problems in curriculum implementation as a stressor, it will be discovered that public school managers are expected to take in fresh students who could hardly read or write. Many could hardly write their own names. The school managers are expected to use their meagre available resources to bring them to conform to standards. Most of them have no option than to do all they could, including mounting remedial programmes, and whatever tricks they could muster to teach these students and bring them to catch up and conform to standards. In this respect, the managers quarrel with their teachers several times to 
attain this. In this respect, the parents, and the ministry most importantly ply dumb and seem not be ignorant of this particular plight of the school heads. None would acknowledge the effort, nor would offer any support. All they want is students to meet up to standards. How it is done and what it takes to do it nobody cares.

The second question was to do with the extent of stress among the school managers. The last item on the inventory dealt with this. From the responses on this item, it was revealed that $77.5 \%$ of the respondents claimed that their job is between stressful to extremely stressful (table 2). Simply put, $77.5 \%$ of school managers in Kano state were stressed. This is irrespective of school location, type, size, gender and years of experience. The important question here is whether the school managers are comfortable with the stress, and that the stress does or does not hinder them in their functions to their capacities. Perhaps their attitudes towards the occupational stress phenomena will certainly matter a lot here, especially as a subject of research studies.

It is only when an appraisal is made of expected roles, functions, duties and expectations of school managers that it will be fully appreciated that they will certainly be stressed. When we consider the job environment itself, it lacks many essential elements as par resource materials to make the job an easy one. Also, their relationship with teachers, parents, ministry officials and proprietors on several occasions may not be an easy and romantic one. In essence they contend with so many problems. These problems range from simple to complex ones. Some are intricately tied to others and so chronic that they are always a source of concern and worries to them.

Perhaps the growing awareness and consciousness about the need to expand and develop education warranted the changes and reforms in education. This has definitely led to an increase in the scope of duties and schedules of school managers. For instance, increase in students' intake, return of boarding facilities, grading of schools, increased demands for accountability and performance. All these put together 
will certainly account for the felt reported stress. On the other hand, the private school mangers were obviously stressed as a result of the need and desire to perform better than the public schools and maintain excellent standards. In order to provide their clients with the right services, and hence establish their excellence over others, the school heads put in not only extra hours of routine work, but in thoughts for developing strategies to attain results.

\section{Conclusion and Implications}

So far, the paper has identified the sources of stress among school managers. The stressors identified been occupational, domestic and economic. Administrative routine and work load and conflicting demands and roles between work and family were identified as the highest stressors to managers. Similarly, most of the respondents, accounting for $77.5 \%$ reported that their jobs were stressful and so they were stressed. The implications of this situation are that, if and unless something is done to arrest the situation there will be serious problems. Occupational stress as a reality world over is known to bring about damaging circumstances to organisations and the attainment of their goals. So in practical sense, there has to be a deliberate and practical attempt to study such a situation with a view to determine the extent of stress and the type of intervention to be used to arrest the state of things.

\section{References}

Abouserie , R. (1996). "Stress, Coping and Job Satisfaction in University Academic Life", Educational Psychology, Vol. 16, No.1

Ajayi, K. (1995). Reflections on the Nigerian Education System: A College Provosts' Perspective. Ijebu Ode, Nigeria: Jimmy Press.

Bennette, J. M. \& Carrol, A.F.B. (1989). "Inoculation against Stress. A technique for beginning teachers." European Journal of Education, 9 (3)

Borg, M. G., et al (1991). "Stress In Teaching: A Study of Occupational Stress and Its Determinants, Job Satisfaction and Career Commitment among Primary School Teachers", Educational Psychology, Vol. 11

Cooper, C.L. \& Marshall, J. (1978). Understanding Executive Stress. London: Macmillan 
Doctor, R. M., \& Doctor, J. N. (1994). "Stress." Encyclopaedia of Human Behaviour, Vol. 4

French, J. R. P., \& Caplan, R. D. (1970). "Psychosocial Factors in Coronary Heart Disease", Industrial Medicine, Vol. 39

French, J. R. P., \& Caplan, R.D. (1973). "Organisational Stress and Individual Strain.” In: Marrow, A. J. (ed), The Failure of Success. New York: AMACOM

Gonzalez, M. A. (1997). A Study of the Relationship of Stress, Burnout, Hardiness and Social Support in Urban Secondary School Teachers. Unpublished $\mathrm{PhD}$ Thesis, Layola, University of Chicago. Dissertations Abstracts International._Vol 57, No. 12

Gowler, D. \& Legge, K. (1975). "The Wage Payment System: A Primary Infrastructure", in Robinson, D. (ed). Local Labour

Hoyle, E. (1989). "The study of schools as organisations." In Vincent, H., Royston, M., \& Colin, M. (eds), Management in Education: The management of Organisations and Individuals. Ward Lock Education / Open University Press

Iwuji, V.B. C. (1990). "Stress and Modern Living. How to Cope with Excessive Stress", Journal of Counselling Psychology, (July) Vol 2, No. 2

Kakabadse, A. (1982). People and Organisations. Aldershot: Grower Publication Company Limited.

Karasek, R. A. \& Theorell, T. (1990). Healthy Work. New York: Basic Books

Khan, R.L., et al (1984). Organisational Stress: Study in Role Conflict and Role Ambiguity. New York: John Wiley and Sons

Levi, L. (1987). "Occupational Stressors, Biological Stress and Workers Health." Journal of the University of Occupational and Environmental Health (Kitakyosho, Japan), Vol. 11

Levi, L. (1990). Occupational stress: Spice of life or kiss of death? American psychologist, Vol. 4 No. 10

Quarles, H. R. (1996). Burnout in heads of independent schools in Southern California, Unpublished PhD Thesis. Dissertations Abstracts International, Vol. 57, No. 7

Swedish Government Commission for Work and Environment and Health (1990). Abeten Utsatta for Sarsskilda halsorrisker (Job exposed to special health risks) Stockholm, Sweden: Allamanna Forlaget. 


\section{Table 1: School Managers Sources of Stress (In Rank Order)}

\begin{tabular}{|c|c|c|c|}
\hline $\begin{array}{l}\text { Stress } \\
\text { Value }\end{array}$ & Stressors & Freq. & $\%$ \\
\hline 1 & Administrative Routine (Occupational Stressor & 32 & $9.4 \%$ \\
\hline 2 & $\begin{array}{l}\text { Work load (Occupational stressor) } \\
\text { Conflicting Demands and Roles between Work and } \\
\text { Family (Domestic stressor) }\end{array}$ & $\begin{array}{l}29 \\
29\end{array}$ & $\begin{array}{l}8.5 \% \\
8.5 \%\end{array}$ \\
\hline 3 & Poor and Unserious Students (Occupational stressor) & 24 & $7.0 \%$ \\
\hline 4 & $\begin{array}{l}\text { Students Indiscipline and Gangstarism(Occupational } \\
\text { stressor) }\end{array}$ & 23 & $6.7 \%$ \\
\hline 5 & $\begin{array}{l}\text { Poor Work Environment (Occupational stressor) } \\
\text { Lack of Resources (Occupational stressor) }\end{array}$ & $\begin{array}{l}22 \\
22\end{array}$ & $\begin{array}{l}6.4 \% \\
6.4 \% \\
\end{array}$ \\
\hline 6 & Economic and Financial Problems (Economic stressor) & 20 & $5.8 \%$ \\
\hline 7 & $\begin{array}{l}\text { Social Problems (Domestic stressor) } \\
\text { Lack of Autonomy in Execution of Responsibilities } \\
\text { (Occupational stressor) }\end{array}$ & $\begin{array}{l}18 \\
18\end{array}$ & $\begin{array}{l}5.3 \% \\
5.3 \%\end{array}$ \\
\hline 8 & Family Pressures (Domestic stressor) & 16 & $4.7 \%$ \\
\hline 9 & $\begin{array}{l}\text { Official Pressure and Expectations (Occupational } \\
\text { stressor) } \\
\text { Group Pressure (Domestic stressor) } \\
\text { Poor Social Image (Economic Stressor) } \\
\end{array}$ & $\begin{array}{l}14 \\
14 \\
14\end{array}$ & $\begin{array}{l}4.1 \% \\
4.1 \% \\
4.1 \%\end{array}$ \\
\hline 10 & Pressure from Teachers (Occupational stressor) & 13 & $3.8 \%$ \\
\hline 11 & $\begin{array}{l}\text { Pressure from Parents (Occupational stressor) } \\
\text { Problems in Curriculum Implementation (Occupational } \\
\text { stressor) }\end{array}$ & $\begin{array}{l}12 \\
12\end{array}$ & $\begin{array}{l}3.5 \% \\
3.5 \%\end{array}$ \\
\hline 12 & $\begin{array}{l}\text { Pressure from Parents Teacher Association (Domestic } \\
\text { stressor) }\end{array}$ & 10 & $2.9 \%$ \\
\hline & Total & 342 & $100 \%$ \\
\hline
\end{tabular}

Table 2: Reponses on General Question on Overall Stress

\begin{tabular}{|l|l|l|}
\hline VALUE LABEL & FREQUENCY & PERCENTAGE \\
\hline Not stressful & 77 & $22.5 \%$ \\
\hline Stressful & 111 & $32.5 \%$ \\
\hline Very Stressful & 101 & $29.5 \%$ \\
\hline Extremely Stressful & 53 & $15.5 \%$ \\
\hline TOTAL & 342 & $100 \%$ \\
\hline
\end{tabular}

